\title{
Learning To Change Together: the social context of architectural learning
}

\author{
Lara Mackintosh, Curtin University, Australia
}

\begin{abstract}
In architectural education learning is often structured to inform and support change to sustainable design and behaviour. The built and natural contexts in which this learning takes place is considered an important element in informing the new ways of seeing and knowing our environments required for change. Yet the social context of learning also affects the opportunities for such transformative learning experiences. This paper discusses how this social context can influence the way in which the learner interacts with the built and natural environment and how this in turn can support transformation. Recent experiences of different models of learning in the US, New Zealand and Australia are used to demonstrate the contexts - social, natural and built - in which learning about the environment in general, and architecture specifically, takes place. An ethnomethodological approach has been taken to develop an understanding of how meaning is made through learning experiences, and how this influences behaviour. Through observations and documentation the nature of social interchange, the role of the natural and built environments and the effect on the learning experiences, both formal and informal, on behaviour are explored. Findings from this investigation will inform the development of a framework for architectural education.
\end{abstract}

Keywords: Learning, Architecture, Social Context, Transformation

\section{Background}

$\mathrm{I}$ $\mathrm{n}$ order to support long term, sustainable behaviour change a better understanding of how learning influences everyday behaviour is required. This paper is part of a research project that aims to develop this understanding and focuses on architectural education. The design and use of architecture contributes significantly to climate change (IPCC 2007), and in architectural education, learning is often structured to inform and support change to sustainable design and behaviour. In exploring how the learning experiences within architectural education can be transformative will support the development of a learning framework for environmental education in general.

In the case of environmental education, where learning is often structured to inform behaviour, and to institute sustainable behaviour change, how do learning experiences affect the development of personal beliefs and values? In addition to formal learning experiences, the informal experience of environment in the everyday also informs our understanding and of these environments, and the nature of our experiences shape the way in which they are valued. In order to understand the complex nature of these learning experiences, an approach has been taken, where learning is seen as a dynamic system comprising of the contexts in which learning takes place, the actors which participate within the system, the interaction and resultant action that takes place between the actors within the contexts.

\section{A system of / for learning}

Four main contexts of learning have been identified as the different situations in which learning takes place. The built environment, the man made physical context of learning, includes formal settings such as schools and other learning institutions, but also includes the everyday built environments in which informal learning takes place. The natural environment is typically a more informal learning environment, though some formal learning programs use the natural environment as the context for learning activities. The educational context for learning incorporates the curriculum and content of the learning, what is being learnt, as well as pedagogical approach of the learning experience. The social context of learning, with whom we learn, has come to the fore in recent research as an important context for learning. This is evident in the development of communities of practice and learning (Wenger 1998) and the application of Blumer's social behaviourism (Blumer 1969) to learning theory. It is this social context that is the focus of this paper.

It is recognised that these four main contexts of learning cannot be considered as discrete when also considering behaviour. This is acknowledged by Walden, who notes that there are many aspects which influence the experience and behaviour of people as they interact with their environments. (Walden 2009). In the past, it has been claimed that environment determines behaviour and that there exists a law-like causal relationship between the two. However, it is difficult to isolate causes and effects, due to the multiple aspects of both the environment and the behaviour. Walden states that an approach where "individual behaviour is not only determined by the social and physical environment, but the individual in turn changes reality by his or her behaviour" (Walden 2009, 3) is more applicable.

This approach recognises the multiples changes that may occur through experience and is applied here, in considering the learning experience as a complex system. It allows for an understanding of the relations, actions and outcomes of learning, namely behaviour, to be developed. As actors, learners and teachers, influenced by one (or more) of the contexts, interact with others, they and their behaviour change. This in turn causes change throughout the system - in the other actors, the contexts and the system itself. This 'systems approach' of understanding change has been applied in sociology since Parsons first described social systems as complex, open and dynamic (Parsons 1965). Studies in social ecology have aimed to forecast outcomes using a systems approach as well, in order to better direct behaviour which occurred in response to uncertainty and rapid change in society and environment as a result of the second industrial revolution. (Emery and Trist 1975). They recognise that using an understanding of complex social systems is important as it can take up to 10 years to identify the impact of social change. In this paper, this understanding of a system of learning supports identification of the potential for change within a system of learning and 
the possible nature of that change to be explored as three case studies of architectural education are presented and evidence of change is discussed.

In most architectural programs, both tertiary and professional, learning experiences are primarily project based, problem solving exercises. Approximately $40-50 \%$ of the curricula content is related to design, with the remainder related to other core areas such as technology, history and theory, environment, and practice. Learning outcomes in design are more often shared through exhibitions and presentations, as design projects are modelled and drawn. In the other core areas, the outcomes, knowledge and understanding, are more difficult to share visually, and the learning experiences are more focussed on the individual. This education system tends to be highly successful in terms of sustainable outcomes, yet doesn't support the change in behaviour required, as climate change continues on the 'business as usual' trajectory. Therefore, it is not considered transformative.

When discussing transformative practices in higher education, Atkin identifies four 'pillars of education' that are experienced throughout life. As learning takes place within each of these pillars, beliefs are challenged, and in doing so, the potential for change, for transformation, is created (Atkin 1999, p.11). Within most architectural programs, it is considered that the first two of these pillars - learning to know and learning to do - are typically experienced within the built, natural and educational contexts. However, the remaining two pillars - learning to live together (social), learning to be (personal) - considered here as most likely to be experienced within a social context, typically are not. The case studies presented here are offered as alternatives to typical architectural learning experiences. Two are tertiary education programs - Rural Studio, conducted as part of the architecture program at Auburn University, Alabama; and the architectural program at the Victoria University of Wellington (VUW), Wellington, New Zealand. The third, 'one2one', was a one day professional development event held in Perth, Western Australia.

While there are identifiable differences in the built and natural contexts, it is the social context of learning in each of these learning experiences that is the focus of this exploration. At Rural Studio the social environment is intense and immersive and integral to the learning experience. In the Victoria University of Wellington School of Architecture, it is the closeness, density and diversity of the social community within Wellington, in which the School of Architecture is located, that is critical. 'one2one', provided an informal learning experience for architectural graduates and experienced architects as a counterpoint to their everyday professional experiences in practice, amongst people they had not met before.

\section{Three architectural learning experiences}

For each of the three case studies, key learning experiences are described based on evidence collected during time spent at each. At Rural Studio and the Victoria University of Wellington, the studies took place over 2 weeks in each program, while one2one occurred in a single day. Evidence collected through observations, field notes, and photographs is used to explore the nature of the social interchange, the role of the natural and built environments and the effect on the learning experiences, both formal and informal. The descriptions tabled below (Tables 1, 2 and 3) are offered as a means of providing an example of the interactions and actions that took place, as representative of the types of learning activities that can took place.

\section{Rural Studio - a learning community}

Rural Studio has at its foundation a sense of social responsibility supported through architectural education and shared learning experiences. The program has been operating out of Newbern, Alabama, for 20 years and the projects designed and built by the students in Newbern and neighbouring towns are easily accessible, and often visible as you move from town to town. The 12-15 third year students participating in the semester long studio live at Rural Studio farm in small cabins that have been built by previous students. The students eat and sleep at the farm, complete their academic work in the studio half a mile down the road, and are expected to participate in the construction of other student designed projects.

\begin{tabular}{|l|l|l|}
\hline Rural Studio & Learning experience & Interactions and actions \\
\hline & $\begin{array}{l}\text { Learning through observation } \\
\text { While one student learns new skills by } \\
\text { completing a set task, others watch. The } \\
\text { student completing the task elected to do so, } \\
\text { and the task involved using equipment that } \\
\text { was unfamiliar and physically challenging. }\end{array}$ & $\begin{array}{l}\text { Students were able to determine which } \\
\text { learning tasks they completed themselves, } \\
\text { challenged. Some of the tasks were required } \\
\text { intellectual skills, while others were more } \\
\text { focussed on physical skills. Not all students } \\
\text { chose challenging tasks, but selected those } \\
\text { that suit existing skills and knowledge. }\end{array}$ \\
\hline
\end{tabular}




\begin{tabular}{|c|c|c|}
\hline Rural Studio & Learning experience & Interactions and actions \\
\hline & $\begin{array}{l}\text { Learning by doing } \\
\text { The new skill learnt requires physical } \\
\text { precision, mental acuity, and accuracy. The } \\
\text { instructor demonstrated the task, providing } \\
\text { an example of the desired outcome. After } \\
\text { attempting the task, the student was given } \\
\text { feedback on how to improve was left to } \\
\text { continue practising. }\end{array}$ & $\begin{array}{l}\text { The student was able to compare outcomes } \\
\text { and relate this directly to the action taken. } \\
\text { By receiving immediate feedback, they were } \\
\text { able to try again, and therefore progress was } \\
\text { immediately evident. Providing the } \\
\text { opportunity to practice on scrap reduced the } \\
\text { severity of the consequences of error, and } \\
\text { encouraged skill development through } \\
\text { practice. }\end{array}$ \\
\hline & $\begin{array}{l}\text { Sharing learning } \\
\text { The same student, after practicing the task } \\
\text { above, was able to demonstrate his progress } \\
\text { to his peers. Comparison with the } \\
\text { instructor's example was made, and the } \\
\text { challenges of the task were explained. }\end{array}$ & $\begin{array}{l}\text { The self-reflection embedded in this } \\
\text { exercise encourages awareness of } \\
\text { development. Recognition of new skill by } \\
\text { peers is seen as positively reinforcing } \\
\text { learning }\end{array}$ \\
\hline
\end{tabular}

Table 1: Rural Studio: third year students completing tasks as part of the 'yard work' exercise during the first week of semester (photos: authors own, 2012).

\section{Victoria University of Wellington, New Zealand - learning in place}

Wellington is a relatively small city, and its topography has resulted in a tight, close knit community within easy reach of natural environments. After completion of a common first year, at the main university campus, students within the School of Architecture and Design (SOAD) focus their subsequent studies on architecture, building science, interior architecture, or landscape, with some units common to all courses. For the remaining four years of the course, most SOAD classes are conducted on a dedicated campus, half an hour away from the main campus. Within the SOAD building year groups from the different disciplines are allocated studio space and classes from most core units are held in these spaces. There is a common exhibition space on the entry level, as well as a resource centre, workshops, lecture theatres and computer labs all of which are typically shared.

While in first year many students live on the main campus in student housing, anecdotal evidence suggested that most students, and some staff members, live within a 10 minute walk of the SOAD campus. The SOAD campus is in the centre of the Wellington CBD, in a vibrant district with a diverse range of activities and building uses, including cafes restaurants, hotels, shops, housing and commercial workplaces. This precinct is also the site of many of the projects set for students.

\begin{tabular}{|l|l|l|}
\hline Victoria University & Learning experience & Interactions and actions \\
\hline $\begin{array}{l}\text { Promoting student work } \\
\text { Display of student work was used to } \\
\text { promote and encourage interest in the } \\
\text { course, to students who may pass through } \\
\text { the space. This is particularly important to } \\
\text { those in the common first year, as they } \\
\text { consider options for more focussed study in } \\
\text { the coming year }\end{array}$ & $\begin{array}{l}\text { The display of work to prospective students } \\
\text { serves to clearly demonstrate the } \\
\text { expectations of the academic programme, } \\
\text { and allows students to assess their own } \\
\text { abilities, capacities and motivation prior to } \\
\text { enrolment. The prospective students are } \\
\text { familiar with some of the actions required to } \\
\text { achieve these outcomes, as prior experience } \\
\text { in achieving similar types of outcomes, at a } \\
\text { different level, as they complete first year. }\end{array}$ \\
\hline
\end{tabular}




\begin{tabular}{|c|c|c|}
\hline Victoria University & Learning experience & Interactions and actions \\
\hline & $\begin{array}{l}\text { Exhibiting for assessment } \\
\text { A critical part of an architectural program is } \\
\text { the display of work for assessment, allowing } \\
\text { instructors to review and critique the final } \\
\text { projects. Often this is accompanied by } \\
\text { formal oral presentations from the students } \\
\text { and / or an official opening, where family } \\
\text { and friends are invited }\end{array}$ & $\begin{array}{l}\text { The opportunity to review, discuss, and } \\
\text { comment on their own work, as well as } \\
\text { those of others, encourages reflection and } \\
\text { promotes development. By including those } \\
\text { from outside the immediate learning } \\
\text { community reinforces a sense of } \\
\text { achievement and progress. }\end{array}$ \\
\hline & $\begin{array}{l}\text { Informal use of space } \\
\text { As the permanent couches and informal } \\
\text { seating immediately adjacent to the } \\
\text { exhibition space are well used, the exposure } \\
\text { of staff and students to current work, and } \\
\text { activities with the programs is increased. }\end{array}$ & $\begin{array}{l}\text { Increased exposure increases awareness of } \\
\text { the progress of students, and awareness of } \\
\text { activities within the broader learning } \\
\text { community. Students are also able to view } \\
\text { work above their year group, which serves } \\
\text { as demonstration of development of recently } \\
\text { learnt skills, and application of skills to } \\
\text { projects. }\end{array}$ \\
\hline
\end{tabular}

Table 2: Victoria University of Wellington: different uses of use of common exhibition space at Faculty of Architecture and Design campus (photos: authors own, 2012).

\section{'one2one' - a professional learning experience}

'One2one' was a one day event held in Perth in 2012. A group of architecture students, and architectural professionals were invited to come together in a community space known as Cityfarm, an urban farm in Perth, Western Australia. The objective of the event was to connect students and professionals, through the design and construction of the interior of a space using only waste or found materials. It was seen as a learning experience as participants applied new and existing skills to problem, while also developing networking and teamwork skills. There were individual briefs for six different tasks as part of the exercise. The materials provided required simple construction skills to manipulate and assemble, and there was an expert on hand for any 'dangerous' work.

\begin{tabular}{|c|c|c|}
\hline one2one & Learning experience & Interactions and actions \\
\hline & $\begin{array}{l}\text { designing as a group } \\
\text { As learners were allocated their groups, the } \\
\text { first actions were as a group, as they became } \\
\text { familiar with the tasks to be completed and } \\
\text { each other. The tasks required significant } \\
\text { problem solving and while this is familiar to } \\
\text { all, the level of skills required to realise the } \\
\text { projects differed. }\end{array}$ & $\begin{array}{l}\text { It became apparent that each participant } \\
\text { came with different levels of confidence and } \\
\text { skills and the initial activity, while involving } \\
\text { the whole group, established hierarchies and } \\
\text { relationships between those with similarities } \\
\text { (of background and skill) were quickly } \\
\text { established. }\end{array}$ \\
\hline & $\begin{array}{l}\text { Individual tasks } \\
\text { While the objective of the exercise was } \\
\text { primarily to encourage networking, or } \\
\text { professional socialising, the initial groups of } \\
6 \text { soon broke down as the participants found } \\
\text { tasks suited to their skills and capabilities. } \\
\text { For many this involved tasks with which } \\
\text { they were familiar. }\end{array}$ & $\begin{array}{l}\text { The opportunity to break into smaller } \\
\text { groups allowed those who felt less } \\
\text { comfortable to remain un challenged. As the } \\
\text { exercise lasted for a day only, with just one } \\
\text { task to be completed, it resulted in limited } \\
\text { opportunities for development and } \\
\text { meaningful learning. }\end{array}$ \\
\hline
\end{tabular}




\begin{tabular}{|c|c|c|}
\hline one2one & Learning experience & Interactions and actions \\
\hline & $\begin{array}{l}\text { Collaborative action } \\
\text { The nature of some of the tasks required } \\
\text { collaboration, as the tasks could not be } \\
\text { completed by individuals. The hierarchies } \\
\text { established at the start of the day were } \\
\text { reinforced as the more confident and } \\
\text { experienced members of the teams were } \\
\text { relied on for decision making and } \\
\text { management. }\end{array}$ & $\begin{array}{l}\text { The familiarity of the tasks, and the } \\
\text { confidence of the learner, influenced the } \\
\text { level of meaningful engagement. It was } \\
\text { easier for those with less experience to take } \\
\text { a more passive role, as the more } \\
\text { experienced participants took control. }\end{array}$ \\
\hline
\end{tabular}

Table 3: one2one: a one day activity intended to promote professional networks through a common exercise of designing a bar and exhibition space from recycled material (photos: authors own 2012).

\section{Evidence of the role of social context of architectural learning}

The role that the social context has in architectural learning is evident in each of the case studies from the interactions and relationships that were observed. The nature of the social interaction itself, the relationships between the students and the contexts in which they are learning, and the capacity of the system to provide opportunities for change, are discussed below as critical to the transformative learning experiences.

\section{The nature of social interchange}

Within the learning experiences, as evidenced in the behaviour and actions of students and staff, there seemed to be a distinct difference in the perception of identity and self - as an individual, and / or part of a collective. Related to this is mutual orientation of like-mindedness. As interaction occurred, and perception of identity and self-developed, recognition of similar values in other participants - like-mindedness - acted to reinforce the perception of self as part of a collective.

\section{Self and collective}

At Rural Studio a strong sense of collective was observed in the different activities, both formal and informal. Many of the learning activities were conducted in groups and as outlined in Table 1 above, supporting peer learning in multiple modes. This served to reinforce the sense of the Rural Studio community, and the position individuals hold within this. This collective identity was strengthened in a local community where newcomers were obvious and Rural Studio students are easily identified and associated with the work done with the community and the positive outcomes.

At Victoria University of Wellington there is a strong collective identity reinforced by the sharing of learning outcomes through exhibitions and visual display. Work exhibited is not only for assessment, but used to promote the various disciplines, programs and events, and display the outcomes of design problems with a community focus. This is reinforced by the dedicated shared building, cross-curriculum and cross-course content and teaching staff, and authentic learning tasks, and results in a sense of individual within a collective that is evidenced in regular participation of professionals in school activities.

Within the one2one event, the two distinct of groups of participants - students and professionals - were clearly evident at the beginning of the day, but as the activities developed, this soon became more difficult to discern. This was assisted by the casual nature of the dress, and the youth of some of the practitioners, and in some cases, the mature age of the students. By the closing 'after-party' these barriers had broken down, and while some had invited friends, work colleagues and family to come down and have a look, there was also evident a sharing of new friendships and relationships that had been developed during the day.

\section{Mutual orientation - like-mindedness}

At Rural Studio there was evidence of a common sense of purpose that related not only to their own performance and willingness to 'do well', but also the increased sense of responsibility that came with the projects themselves, supported by the nature of the projects. While the students were working on a project to benefit Rural Studio Farm, there it was clear that this could lead to a more public community project, such as the ones worked on by the fifth year students. There is also a sense of collective in that it is made clear to the students the work that they are doing will be referred to and relied upon by future students, as the nature of the projects extends beyond the single semester they are there. This is reinforced by the fact that they are required to refer to work of previous students as part of their research and analysis of their own projects. It results in a common approach to problem solving that is identifiably 'Rural Studio'.

At Victoria University of Wellington, the focus of the student work was reflective of a common sense of responsibility. Recently, other parts of New Zealand had been affected by earthquakes, which had left a significant impression not only on people's lives, but also the built environment. It seemed apparent that the students were able to identify with this. The focus on compliance with building regulations was not questioned by students, staff or visiting 
professionals, and in some cases became the source of inspiration. It seemed that recent events had increased the relevance of such considerations, and in turn had the potential to shift the students attitude towards the issue.

During the one2one event, there was an evident sense of identity as a collective, as people referred to themselves as sustainable or "green". This was reinforced through the focus of the tasks, which was the reuse and re-lifing of waste material. However, it became clear during the interviews at the end of the event that this resulted in minimal change in value orientation as the learning experience supported existing values but didn't challenge them.

\section{Relationships between actors and context}

The scale of the context, be it social, natural or built, has an effect on the learning experience. In contexts where the scale is large, it is difficult for students to engage with all aspects of the contexts and for the interaction to be meaningful. Where the scale is more intimate, or appropriate to task, the learning experience has an opportunity to be meaningful. In addition, the capacity to control the contexts of their learning can influence the development of skills and knowledge and the way in which this can change every day behaviour. When there is little control over the learning experience by the student, and students are directed as to what to do, the learning experience is often transmissive, but may have limited meaning for the student, inhibiting transformation.

\section{Scale and density}

This influence of the density of the contexts is evident at Victoria University of Wellington where despite the typical year group comprising around 120 students, the closeness of the community in which the Victoria University of Wellington campus was situated was supported by the built context. As most people lived, played and worked within walking distance of the campus, the reduced size of the physical context increased the density of the social context. In Rural Studio, the immediate community of the town was small, as the town had a population of about 200 . The immediate Rural Studio community was even smaller, and this reinforced social connections. In one2one the already small groups of 6-8 naturally broke down into pairs, as the participants became increasingly engaged in tasks. This was not choreographed by the organisers but occurred organically as people found their own way of working within a new physical and social context.

\section{Control and responsibility}

At Rural Studio, the learning for the third years are centred on a single project, typically for the Rural Studio community itself. Tasks undertaken as part of the studio work related directly to the understanding of the issues and the solving of the immediate problem. The less formal exercises, such as the yard work, could be seen as directly related to their own learning as they explored their individual capacities and skills, which they would rely on later in semester. In this way, they could control the level of difficulty and pace of development to suit their own needs, and to do so with an understanding of the final outcomes, as the skills they were developing could be seen in the fifth years, also working on sites nearby.

At Victoria University of Wellington architecture students exploring the design response to seismic events were able to see and hear firsthand about others experiences for staff and the visiting practitioners. In addition, work of other students relating to the same were on display at the same time. The sharing of experiences, both real and vicarious, seems to support the sense of responsibility of the students. The knowledge and skills developed could be seen to provide an element of control over a situation that must at times seem out of control.

For those participating in the one2one event, all materials and information were provided for all participants and they then, in groups, used existing skills to create their designs, and find the materials needed. The teams approached the task in two ways. One was to establish a design idea or concept, and then search for the materials to suit. This was possible as groups were allowed to barter. Others looked at what they had, and developed their design concept around what was available. While both seemed to be successful, they offered different ways in which to control the outcomes, yet the primary decision of the type of materials, in this case recycled, was made, and reflected the main focus of the activity and the values of those participating.

\section{Opportunities for change}

In the case studies there are a number of key components of the learning experience that contribute to the resulting change in the system, seen here as evidence of transformative learning. Where the task or learning activity reflects an aspect of their daily practice, or can be applied to their immediate environments, the experience is likely to support change. Where the task is clearly defined, the objectives explicitly stated, and the development immediately recognisable the participant is more likely to engage in the learning experience and the experience is often more meaningful. For formal learning tasks this is more likely as there are often defined briefs and tasks set, this can be supported through the informal learning opportunities. Transformative learning can also be supported by encouraging the student to be more aware of their own development and learning. Within architectural education, awareness of development is often easily supported as students are required to exhibit, review and critique their own and their peers works often.

\section{The relevancy of the experience}


At Rural Studio, the skills learnt during the yard work went beyond the construction skills. As students were encouraged to move around, and explore, they quickly 'found their fit' and gravitated towards tasks and environments that suited them. Informal discussion with the students during lunch indicated that some students while finding the tasks challenging they were pleased they had pushed themselves and accomplished the task at hand. This then supported the development of skills such as leadership and resilience (pushing through a challenge) when completing the project tasks. This was also evident in one2one where the task was easily accomplished in one day and the sense of accomplishment was high. Some had taken the opportunity to do new things, while for others, the event presented an opportunity to reinforce existing skills and previous learning. As a result, many did not see the event as a learning opportunity.

Engagement was also supported where the tasks were linked to their immediate contexts especially where the end, the outcome of the learning, was focussed on the learning community needs rather than the individual needs. In the case of Rural Studio, the tasks and learning was directly related to their own community as well as the local community. At Victoria University of Wellington the project tasks were directly related to the perceived threat of imminent earthquakes, and the affect that this might have on their own and broader communities.

\section{Awareness of group and self-development}

In the working environments of the students at Rural Studio, and Victoria University of Wellington, this is evident in the ongoing and informal display of work by the students. Sketches, models and works in progress are displayed wherever there is an available flat surface. In this way students are able to become more aware of the development made, and the learning is more evident to the student, and their colleagues. During the one2one event, the structuring of the tasks and the group influenced the outcomes. Some groups broke the task into smaller tasks, which served as milestones along the way and required them to regroup frequently, offering opportunities to reflect, review and plan as a group. Alternatively, where a group produced a number of individual solutions rapidly, these were quickly dismantled and the project started again. In this case, while the final outcomes were as tangible, and many stated their pride and sense of satisfaction, not many saw the experience as one that had developed skills or recognised that learning had taken place, despite expressing that they had learnt about themselves and teamwork.

\section{Transformative learning}

Atkin states that transformative learning occurs as a result of dynamic interaction with others, and personal growth through constructing and reconstructing our meanings and values, our beliefs, of and about the world (Atkin 1999). It is as we experience the world, in many ways and in different contexts, that the opportunity to learn and transform is made, and change occurs. This view of transformative learning is supported by Jack Mezirow who defines transformative learning as "the social process of construing and appropriating a new or revised interpretation of the meaning of one's experience as a guide to action." (Mezirow 1994, 222-3). Critical to this is the requirement for a new or revised interpretation of experience - perspective transformation - which in turn influences further experiences and action within the system. In a literature review investigating models of educational practice supporting perspective transformation, Taylor identified four critical elements across a number of studies. Disturbing dilemma, or a challenging of assumptions and beliefs; opportunities for critical reflection that support a reassessment of orientation; the context, both social and physical surrounds of the learning experience; and relationships, as an 'other way of knowing (Taylor 1997, 45-49).

\section{Recognising change in a learning system}

Mezirow identified the outcome as a change in perspective, which has come about through a challenging of assumptions resulting in new understandings, comes an increase in self confidence in new roles and relationships (Taylor 1997, 49). Taylor found a number of examples of outcomes of change brought about by perspective transformation such as changes in the understanding of oneself; convictional changes seen in a revision of a belief system; behavioural changes in lifestyle; increase in personal power; increased compassion for others; and a new connectedness with others (Taylor 1997, 49-50). Some of these are considered here as observable and identifiable in behaviour, and examples of such behaviour were looked for in the evidence collected. In the case studies presented, staff, students and recent graduates of the programs at Rural Studio and Victoria University of Wellington exhibited confidence in new situations or at levels higher than expected; a commitment and compassion for others greater than expected; and high levels of connectedness with others.

\section{Increased confidence}

At Rural Studio, the fifth years exhibited a confidence that was not evident in the third years. While some of this confidence comes with the increase in age and maturity, it seemed to extend beyond that seen in other architectural programs. The fifth years negotiated the cost and supply of materials for the planned build, met with community members regarding design intent and progress, and consulted with local artists and practitioners. In doing so they demonstrated skills and abilities that are listed as professional competencies looked for in those seeking registration (Architects Accrediation Council of Australia 2008), a process which can occur only two years after graduation.

Similar to the fifth years at Rural Studio, the tasks completed by the students at Victoria University of Wellington, which included project and team management, research project definition and completion, negotiation with the 
university regarding funding and support in kind, all indicate a confidence beyond that normally expected. The four team members had also established an architectural firm with one of the staff members who supported the Firstlight Project, the school entry for the international Solar Decathlon Competition (Victoria University of Wellington 2011). This is seen as not only related to confidence, but also evidence of ongoing connectedness with others, as none of the team knew each other prior to the projects initiation.

\section{Commitment and compassion for others}

The environmental commitment of the Firstlight project has been continued by the team who state that "technology and sustainability should not only be affordable, they should also meld around how we live as" as part of their vision (First Light Studio 2013). Increased compassion for others was also evident in the work on display at Victoria University of Wellington as the projects relating directly to recent catastrophic events in New Zealand had outcomes for the community that extended beyond that of the assessed projects. At Rural Studio, many of the final year students expressed and exhibited an obvious compassion for others. This was evident in the fact that during my stay, there were two groups of 'leftover thesis' students, the name given to students who had elected to stay on beyond the completion of their formal education, so they could complete the project they had started as part of their studies. For some students, they were in their second year, having graduated two years previously.

\section{Connectedness with others}

Connectedness with others was also evident at Rural Studio, particularly in the staff. Some of the staff are alumni of the program, and had stayed on or elected to return, and when interviewed recognised that the relationship with the students and the local community was a primary reason for this. This strong sense of identity and connection supported by the social context. As a part of the process of completing their studies at Victoria University of Wellington, the team who initiated, lead and eventually saw success with the Firstlight project also developed strong connections evident in the ongoing involvement in teaching at Victoria University of Wellington, as the program has strong professional and industry involvement.

\section{Limitations to recognising transformation}

As the duration of the one2one event was short, a single day, and this was the first time this event was held in Perth, it is difficult to recognise long term change in the participants. However, the transformative opportunities seemed to be most effective for the students, for whom the social context was the most challenging. Evidence of this can be found in similar groups of students who regularly participate in similar events, as it is often these students who are most active in their student's community, and contribute regularly to non-curricular events. However, for the professionals, the experience was typically not seen as a learning experience, and while engaging, the activity did not challenge their beliefs, but served to reinforce existing beliefs. Some participants admitted that their motivation was to network and meet new people, and when asked they did not see this new understanding as learning, and saw limited opportunity to use this new understanding after the event, in professional or academic life.

\section{Conclusion}

In traditional programs of architecture, due to the inherent nature of what are often authentic learning experiences in terms of the built, natural and educational context of the learning experiences, the social connections developed in the formal learning environment often form the foundation for future professional networks. Yet these learning experiences may not result in transformation, and the social networks founded consolidate existing beliefs, and have not arisen from the new interpretation of experience, that is considered the outcome of a transformative learning experience. The case studies presented here have been offered as examples of learning experiences that have supported such transformation. At Rural Studio the intensity of the social context supports strong commitment and connection to others that can be seen developing in the students as they return as fifth years, and in the staff who are often alumni of the program. At Victoria University of Wellington, the outcome of the learning experiences in the School of Architecture, while similar to those seen at other universities, has supported the development of confidence and commitment in graduates that is more often seen in professionals of two or more years' experience. In the case of the professional learning experience, one2one, the experience seemed more transformative for the students participating, as the social context in which the event was held was challenging.

It seems therefore that the social context of learning can influence the transformative opportunities of a learning experience. The evidence offered through the case studies offers support for the consideration of the social context within a learning system. The discussion has provided some key points worthy of further consideration, and in identifying a way of recognising behaviour change, it has provided a direction for the future development of a framework for architectural education. 


\section{References}

Architects Accrediation Council of Australia. 2008. The National Competancy Standards in Architecture. Canberra: Architects Accrediation Council of Australia.

Atkin, J. 1999. Values for a Learning Community: Learning to Know. In Victorian Principals' Conference. Melbourne. Blumer, H. 1969. Symbolic Interaction: perspective and method. Englewood Cliffs, N.J.: Prentice Hall.

Emery, F. C., and E. L. Trist. 1975. Towards a Social Ecology. New York, NY: Plenum Publishing.

First Light Studio. Our Vision 2013 [cited 3 May 2013. Available from http://firstlightstudio.co.nz/about/ourvision/.

IPCC. 2007. Working Group IV: Synthesis Report In Climate Change 2007: Fourth Asssessment Report.

Mezirow, J. 1994. Understanding transformational theory. Adult Education Quarterly 44:222-32.

Parsons, T. 1965. An Outline of the Social System. In Theories of Society: Foundations of Modern Sociological Theory, edited by T. Parsons, Shils, E., Naegele, K., Pitts, J. New York: The Free Press.

Taylor, E. W. 1997. Building Upon the Theoretical Debate: A critical reveiw of the empirical studies of Mezirow's transformative learning theory. Adult Education Quarterly 48:34-59.

Victoria University of Wellington. firstlighthouse 2011 [cited 3 September 2012. Available from http://firstlighthouse.ac.nz/.

Walden, R. 2009. Schools for the future: design proposals from architectural psychology. Cambridge. Mass.: Hogrefe $\&$ Huber.

Wenger, E. 1998. Communities of Practice: learning, meaning and identity. Cambridge, U.K.: Cambridge University Press.

\section{ABOUT THE AUTHOR}

Lara Mackintosh: Lara Mackintosh has over 15 years' experience in the profession working in the residential, retail and educational sectors. Now, as an academic in Perth at Curtin University School of Built Environment, Lara has been developing her keen interest sustainability in architecture through her research and teaching practice. Her current research activities are associated with developing a holistic approach to architecture, in which the social, economic and environmental issues of sustainability in the built environment can be addressed both through practice and the education of architects. Lara is currently exploring this as a $\mathrm{PhD}$ candidate. The focus of her thesis is the development of a pedagogical framework for environmental education to support long term sustainable behaviour. 